\title{
Blood Cells and Leukocyte Culture - A Short Review
}

\author{
Syeda Juveriya Fathima* and Farhath Khanum \\ Department of Biochemistry and Nanosciences, Defence Food Research laboratory, India
}

Submission: April 01, 2017; Published: May 08, 2017

*Corresponding author: Syeda Juveriya Fathima, Department of Biochemistry and Nanosciences, Defence Food Research Laboratory, India, Tel: +917892040596; E-mail address: juveriya.sjf@gmail.com

\begin{abstract}
Whole blood is the red fluid constantly circulating in our blood vessels (arteries and veins) in order to supply nutrition and oxygen to the body and removal of waste substances. This fluid consists of numerous cells (erythrocytes, leukocytes and platelets) and proteins suspended in the plasma. Blood has three main functions: transportation, regulation and protection. There is no substitute for blood and cannot be manufactured. Blood loss is controlled by clotting factors present and white blood cells provide immune response. Thus, blood cells play vital role in normal functioning of human body. It is the purpose of this review to describe the types and role of blood cells in human body and brief description of leukocyte culture.
\end{abstract}

Keywords: Blood; Leukocytes; Plasma; Thrombocytes; Chromosomes; Mitosis

\section{Introduction}

Blood is a body fluid that consists of four components namely plasma, erythrocytes, leukocytes and thrombocytes. The whole blood is divided into 55 percent plasma and 45 percent cells making 8 percent of total body weight [1]. An adult human body contains about 5 litres of blood. The important functions of blood are transport of nutrients and oxygen to different organs and tissues, fetching antibodies to desired site of action in order to fight against infection, waste products transport for detoxification in liver and kidney, regulate body temperature and transport of hormones to desired site of action. Blood also wipes out waste from the body. The study of blood is known as haematology. Plasma is the coloured liquid constituent of the blood consisting of water $(90 \%)$, proteins, sugars, fat and salts (sodium, potassium, chloride and calcium). Plasma transports blood cells along with nutrients throughout the body. Blood cells like RBC, WBC, platelets and other constituents like nutrients, electrolytes, antibodies, vitamins, clotting factors, hormones float in plasma. Serum is the plasma without clotting factors. All blood cells are formed by pluripotent hematopoietic stem cells in bone marrow by a process called haematopoiesis.

\section{Erythrocytes (RBC)}

RBC's is the most abundant of the three types of blood cells in our body. They differ due to the absence of nucleus (anucleated) which makes them more flexible. They shape is biconcave disk with flattened centre. They contain a protein called haemoglobin which holds oxygen from lungs and supplies to the rest of the body. The red colour of the blood is also due to the presence of haemoglobin which comprises iron that binds to oxygen, to give blood its red colour. They function as transportation system of the body by carrying oxygen from the lungs to other cells of the body and carbon dioxide produced by the body as waste transported back to lungs in order to eliminate from the body. The production of RBC in blood is controlled by a hormone called erythropoietin which is formed by kidneys. The red blood cell survives on average of just 120 days.

\section{Leukocytes (WBC)}

White Blood Cells are also called leukocytes. They play a vital role in immune system by protecting the body from invading infection. If one notices more number of WBC in the blood circulation, it means manifestation of prevailing infection in the body. They can be called as police officers as they look for pathogens invading the body. They can be further divided into two depending on the presence of granules in their cells. They are: granulocytes and agranulocytes. Granulocytes are further classified into three types of WBCs. They are: Neutrophils, Eosinophils, Basophils. Agranulocytes are further classified into Lymphocytes and Monocytes. Neutrophils play a vital role in killing off foreign objects especially bacteria by phagocytising bacteria in our bodies. Eosinophils role is to fight infections of parasitic worms by releasing toxins. Basophils function 
by releasing two chemicals, histamine (allergic reactions) and heparin (anti coagulant). Monocytes are responsible for phagocytising foreign substances by the formation of macrophages. Lymphocytes are major white blood cells that are further differentiated into T lymphocytes and B lymphocytes. $\mathrm{T}$ lymphocytes (Thymus dependent cells) function through cell mediated immunity and directly attack various infected cells and tumours. B lymphocytes (Bursa dependent cells) are responsible for humoral immunity as they produce antibodies which specifically target bacteria, viruses, and other foreign materials. Lymphocytes differ from other WBCs by having memory power of recognising invading foreign materials.

\section{Human Leukocyte culture}

Whole blood consists of RBC, WBC and platelets. Since RBC's are enucleated they can't be used for chromosomal culture. Under appropriate conditions, active leukocytes (nucleated) can be used for in vitro studies. The purpose of leukocyte culture is to get adequate number of metaphases to allow chromosomal analysis. Peripheral blood consists of T-lymphocytes that are differentiated cells which do not undergo further cell division. Hence, leukocytes are grown in rich culture medium (RPMI 1640 with low thymidine content) and bovine calf serum (natural environment for dividing cells). Phytohaemagglutinin (PHA), a mitogen or mucoprotein is used to transform large numbers of leukocytes to enter mitosis. PHA exposure leads to morphological transformations like RNA and DNA synthesis and nuclei enlargement. M phase occupies only small part of cell cycle. The cells are incubated for 72 hours to get the optimum mitotic index. At this stage, mitotic index is increased by addition of colchicine (mitotic inhibitor) to the culture which prevents formation of mitotic spindle thereby arresting mitosis in metaphase stage. Thus cells are unable to leave thereby get accumulated in metaphase of mitosis. Further the cells are harvested and treated with hypotonic solution $(0.56 \% \mathrm{KCl})$ to induce swelling so that the chromosomes are dispersed well and the cells are fixed by Carnoy's fixative (methanol : acetic acid = 3:1). The collected leukocytes suspension should be dropped on chilling slides from a distance of 2-3 feet and stained using Giemsa staining for chromosomal analysis [2-4].

\section{Platelets}

Platelets also known as thrombocytes are not cells rather fragments of cells without nucleus formed in bone marrow by large megakaryocytes. They play a major role in blood clotting by forming a platelet plug at the site of injury that leads to formation of clot by arresting the further flow of blood through the wound, thus promotes healing of wounds.

\section{Conclusion}

The article provides useful information of role of erythrocytes, leukocytes and platelets in maintaining health by stimulating immune response, wound healing, transport of nutrients and waste in and out of the body. Decrease in number of blood cells leads to various diseases like anaemia due to lack of iron or vitamins in diet or inherited genetically. These diseases and related symptoms demonstrate how important blood cells are to your daily life.

\section{References}

1. Dennis O'Neil (1999) Blood Components. Palomar College, California.

2. Dunn PM (1974) Respiratory distress syndrome and continuous positive airway pressure. Proc R Soc Med 67(4): 245-247.

3. Kanagawa H, Basrur PK (1968) The Leukocyte Culture Method in the Diagnosis of Free-martinism. Can J Comp Med 32(4): 583-586.

4. Moorhead PS, Nowell PC, Mellman WJ, Battips DT, Hungerford DA (1960) Chromosome preparations of leukocytes cultured from human peripheral blood. Exp Cell Res 20(3): 613-616.

\section{Your next submission with Juniper Publishers will reach you the below assets}

- Quality Editorial service

- Swift Peer Review

- Reprints availability

- E-prints Service

- Manuscript Podcast for convenient understanding

- Global attainment for your research

- Manuscript accessibility in different formats ( Pdf, E-pub, Full Text, Audio)

- Unceasing customer service

Track the below URL for one-step submission https://juniperpublishers.com/online-submission.php 